\title{
Jaboticaba skin flour: analysis and sustainable alternative source to incorporate bioactive compounds and increase the nutritional value of cookies
}

\author{
Carline MARQUETTI ${ }^{1}$, Tatiane Batista dos SANTOS $^{1}$, Kelen Fabiana Cavalli KAIPERS ${ }^{1}$, Bruna Raquel BÖGER ${ }^{1}$, \\ Ivane Benedetti TONIAL ${ }^{2}$, Americo WAGNER JUNIOR ${ }^{3}$, Luciano LUCCHETTA ${ }^{1 *}$, Naimara Vieira do Prado ${ }^{4}$
}

\begin{abstract}
Jaboticaba (Plinia cauliflora) is a Brazilian native fruit which can be consumed in natura form, and also as processed food. The skin has a significant biological nutritional potential. The present study aimed to evaluate the bioactive compounds of the jaboticaba skin and of the jaboticaba skin flour (JSF), and its application in cookie. Physicochemical analyses to determine the bioactive compounds and antioxidant activity (TEAC and FRAP) of jaboticaba skin and JSF were performed. Skin presented high content of phenolic compounds, anthocyanins, flavonoids and condensed tannins, strengthening that this composition exhibited considerable levels of antioxidant activity. The JSF presented considerable carbohydrate contents, phenolic compounds and antioxidant activity, besides being a source of fibers. The cookies were prepared by replacing $2.5 \%, 5.0 \%$ and $7.5 \%$ of the total amount of whole wheat flour in the recipe by JSF. The formulations presented positive increases of bioactive compounds, contributing with the potential of antioxidant activity. All formulations were well accepted in the sensory evaluation.
\end{abstract}

Keywords: native fruits; biscuits; residues; postharvest; foods; bioactive compounds.

Practical Application: Use of sub products of Jaboticaba (skin) for incorporation of nutrients into cookies.

\section{Introduction}

Jaboticaba (Plinia sp.) is a Brazilian native fruit that has nice sweet flavor and mild acidity. It can be consumed raw or industrialized as juice, jelly, liquor and in fermented products. This fruit has a significant number of bioactive compounds responsible for its substantial antioxidant activity (Wu et al., 2013).

The jaboticaba skin is seen as waste and is often discarded, despite the beneficial properties of this fruit. There is the trend of fully using wastes due to an increasing need, mainly in the modern industry, to develop environmental management systems that meet the ISO 14000. The fruit wastes (mainly the skin) have been studied in order to be used as raw material in the development of new products or to aggregate bioactive compounds to food. Fruit skins such as those from banana (Dan et al., 2015); cashew peduncle (Alcântara, et al., 2012) and grape (Lopes et al., 2014), among others, are processed into flours, in order to use this waste to prepare food.

The previously described beneficial components found in the jaboticaba skin (Oliveira et al., 2003) allow turning this fruit waste into flour in order to have it applied to food products or to use it as food supplement, fact that enables the increased use of jaboticaba fruits. In the literature, different studies have been carried with jaboticaba. Lima et al. (2011) evaluated different anthocyanin extraction processes as well as pigment stability and antioxidant activity of skin, seed and pulp. Zago et al. (2015), prepared cookies for school food using jaboticaba skin, in which they evaluated only physical and sensorial characteristics.

Studies have described the high content of phenolic compounds, such as anthocyanins, in jaboticaba skin (Santos et al., 2010; Cavalcanti et al., 2011). Such part of the fruit is often discarded due to the presence of tannins able to give astringency to the food.

The anthocynins play an important role in inhibiting oxidative and inflammatory diseases. In addition, they may mitigate oxidative stress associated with chronic degenerative diseases such as diabetes and cancer (Koenig et al., 2011; Chang et al., 2016), and may also be used to treat hemoptysis, asthma, enteral dysfunction and inflammation in the tonsils (Santos \& Meireles, 2009).

Furthermore, jaboticaba is a substantial vitamin C (Lima et al., 2006) and flavonoid source. Flavonoids are polyphenols responsible for the sensory profile of fruits. They are acknowledged for the capture and neutralization of oxidizing species, since they are able to bind to the metabolic ions found in the oxidizing species in order to prevent them to work as catalysts in the production of free radicals (Trueba \& Sanchez, 2001).

The most diverse fruits are used for the purpose of taking advantage of functional properties, such as pulp and banana skin, whether mature or immature, grape products (must,

${ }^{1}$ Departamento de Engenharia de Alimentos, Universidade Tecnológica Federal do Paraná - UTFPR, Francisco Beltrão, PR, Brasil

${ }^{2}$ Departamento de Química, Bioquímica e Biologia, Universidade Tecnológica Federal do Paraná - UTFPR, Francisco Beltrão, PR, Brasil

${ }^{3}$ Faculdade de Agronomia, Universidade Tecnológica Federal do Paraná - UTFPR, Dois Vizinhos, PR, Brasil

${ }^{4}$ Departamento de Física, Estatística e Matemática, Universidade Tecnológica Federal do Paraná - UTFPR, Francisco Beltrão, PR, Brasil

*Corresponding author: lucchetta@utfpr.edu.br 
bagasse, skins, among others), skin of passion fruit, apple, mango, potatoes and orange (Ascheri et al., 2006; Fernandes et al., 2008; Souza et al., 2008; Borges et al., 2009; Alkarkhi et al., 2011; Ferreira et al., 2012). One of the raw materials that can be used for the elaboration of differentiated flours is jaboticaba peel, since it covers bioactive properties, which lead to health benefits through the compounds of antioxidant nature, which can also aid in food preservation and in addition they have fibers, minerals and carbohydrates.

In the present study, was evaluated the physical and chemical properties and bioactive compounds in the skin jaboticaba and flour, as well as the technological application for the preparation of cookies and evaluation of maintaining the nutritional and bioactive properties in the product.

\section{Materials and methods}

\subsection{Sampling}

Jaboticaba Açú Paulista (Plinia cauliflora) samples were collected from native plants grown in a rural property located in Pato Branco County-Paraná. Approximately $15.0 \mathrm{~kg}$ of whole and harvesting-stage ripe fruits were selected. The samples were previously washed in running water and in $15 \mathrm{mg} / \mathrm{L}$ sodium hypochlorite solution for 15 minutes. Next, the pulp and the seeds were separated from the skin. In the separation, part of the pulp is fixed to the skin and another part is attached to the seed. The seeds were stored for other work. The skins were packed and stored at $-18{ }^{\circ} \mathrm{C}$ to further use. Subsequently, the skins were transferred from the freezer to the refrigerator at $5^{\circ} \mathrm{C}$, for 24 hours, in order to defrost. The total amount of skins was split in two parts; one part was subjected to physicochemical and bioactive compound featuring, whereas the other was used in flour preparation.

\subsection{Flour preparation}

The jaboticaba skins were dried in an air-circulation oven at $60 \pm 5{ }^{\circ} \mathrm{C}$, for 10 hours. Next, they were ground in food processor and sieved on 20-50 mesh in order to produce flour.

\subsection{Preparing the cookies}

The cookies were prepared by replacing $2.5 \%, 5.0 \%$ and $7.5 \%$ of the total amount of whole wheat flour in the recipe by jaboticaba skin flour (JSF) (Table 1). The rates were set according to results of pre-tests using jaboticaba skin flour (flakes) added to the cookies. A standard formulation (without the addition of JSF) was developed in order to compare the results. The cookie preparation procedure was based on studies carried out by Ferreira et al. (2012).

\subsection{Analyses}

\section{Basic chemical analyses}

The moisture, ash, protein and crude fiber analyses were performed according to the 103 standards set by Instituto Adolfo Lutz (2008); the lipid analysis was conducted as per Bligh \& Dyer
(1959); the carbohydrate and the energy value analysis followed the methodology by Osborne \& Voogt (1978).

\section{Quantifying the bioactive compounds}

Jaboticaba skin and jaboticaba skin flour samples, as well as cookie samples, were prepared as hydro alcoholic extracts, according to the description by Brand-Williams et al. (1995), in order to perform the bioactive compound quantification analysis. The quantification of bioactive compounds was spectrophotometrically performed using the wavelength suitable for each analyzed compound.

The 765-nm wavelength was used to determine the total phenols, as described by Folin-Ciocalteu (Singleton et al., 1999), and the results were expressed in GAE - Gallic Acid Equivalent ( $\mathrm{g}$ GAE $100 \mathrm{~g}^{-1}$ ). The methodology described by Zhishen et al. (1999) was used to analyze the total flavonoids, and the extract reading was performed at $510 \mathrm{~nm}$. The results were expressed in mg of catechin equivalents (CE) per $100 \mathrm{~g}$ of the fruit. The total anthocyanin contents were determined through the differential pH method (Lee et al., 2005). Firstly, pH 1.0 (KCl 0.025 M) and $\mathrm{pH} 4.5\left(\mathrm{C}_{2} \mathrm{H}_{3} \mathrm{NaO}_{2} 0.4 \mathrm{M}\right)$ buffer solutions were prepared. Then, the absorbance reading was done at 520 and $700 \mathrm{~nm}$, and the value of the anthocyanins was expressed in mg Cy-3-glucoside $100 \mathrm{~g}^{-1}$. The condensed tannins were set through the methodology by Queiroz et al. (2002), whose extract in the samples was read at $540 \mathrm{~nm}$. The results were expressed in $\mathrm{g}$ per100 $\mathrm{g}$.

\section{Antioxidant activity}

The DPPH antioxidant activity was determined through the DPPH method (2,2-diphenyl-1-picryl-hydrazyl), with modifications by Rufino et al. (2007). The scavenging activity of the free radicals was set through the Trolox ${ }^{\circledR}-\mathrm{DPPH}$ standard curve, which was read in spectrophotometer at $515 \mathrm{~nm}$. The final result was expressed as TEAC (Trolox ${ }^{\circledR}$ Equivalent Antioxidant Capacity) in $\mu \mathrm{M}$ TE per g. The total antioxidant activity was determined through the FRAP (Ferric Reducing Antioxidant Power) method, according to Rufino et al. (2006).

Table 1. Formulation of cookies produced with the addition of Jaboticaba Skin Flour (JSF) in differents percentages.

\begin{tabular}{lrrrc}
\hline \multirow{2}{*}{\multicolumn{1}{c}{ Ingredients }} & \multicolumn{4}{c}{ (\% JSF) } \\
\cline { 2 - 5 } & $(0.0 \%)$ & \multicolumn{1}{c}{$F 1$} & $F 2$ & $F 3$ \\
& $(2.5 \% \mathrm{JSF})$ & $(5.0 \% \mathrm{JSF})$ & $(7.5 \% \mathrm{JSF})$ \\
\hline Whole wheat flour & 31.07 & 28.57 & 26.07 & 23.57 \\
'JSF flakes & 0.00 & 2.50 & 5.00 & 7.50 \\
Maize starch & 15.53 & 15.53 & 15.53 & 15.53 \\
Brown sugar & 7.77 & 7.77 & 7.77 & 7.77 \\
Refined white sugar & 7.77 & 7.77 & 7.77 & 7.77 \\
Oat flakes & 7.77 & 7.77 & 7.77 & 7.77 \\
Chemical yeast & 1.94 & 1.94 & 1.94 & 1.94 \\
Vanilla essence & 0.97 & 0.97 & 0.97 & 0.97 \\
Margarine & 15.53 & 15.53 & 15.53 & 15.53 \\
Eggs & 11.65 & 11.65 & 11.65 & 11.65 \\
\hline
\end{tabular}

${ }^{1}$ Jaboticaba skin flour. 
The spectrophotometer readings were performed at $595 \mathrm{~nm}$ and the results were expressed in $\mu \mathrm{M} \mathrm{FeSO} \mathrm{g}^{-1}$.

\section{Sensory analysis}

The project was submitted to the Human Research Ethics Committee, prior to the sensory analysis, in order to be assessed and approved according to Ministry of Health Resolution $466 / 2012$. Thus, the tests were conducted after the approval number 267.361, from May $9^{\text {th }} 2013$, was issued by the Research Ethics Committee of the UTFPR. The formulations were previously subjected to microbiological analyses in order to assure the quality of the herein prepared product. The cookies were subjected to a 9-point-hedonic scale acceptance test (from 'I like it very much' to 'I dislike it very much') based on attributes such as flavor, color, aroma, texture and overall impression (OI), according to Stone \& Sidel (2004). Thus, 100 untrained, randomly selected appraisers were recruited. They have signed an informed consent form and provided personal data such as age and gender. The appraisers addressed the cookies according to a 7-point scale (from 'I would often eat it' to 'I would never eat it') in order to make it possible assessing the purchase intent. The tests were performed in the Sensory Analysis Laboratory cabins at UTFPR - Francisco Beltrão Campus.

\subsection{Data analysis}

Data concerning the skin, flour and cookie analysis showing no normality in the Lilliefors test were standardized through the equation $\sqrt{x+1}$ (Cruz, 2006). The skins and the skin flour were subjected to analysis of variance (ANOVA) and to Duncan's test at $5 \%$ significance level $(\mathrm{p}<0.05)$, after they were standardized. The cookies were subjected to Pearson's correlation test and to analysis of variance, using simple linear regression at $5 \%$ significance. The sensory analysis results were compared through the nonparametric Kruskal-Wallis test at $5 \%$ significance. The principal component analysis was used in the joint assessment of the attributes. All the analyses were performed in the XLSTAT software (Addinsoft, 2015).

\section{Results and discussions}

\subsection{Physical and chemical characterization}

Significant differences $(\mathrm{p}<0.05)$ between values were observed in each variable, when the jaboticaba skin was compared to the jaboticaba skin flour. The moisture in the jaboticaba skin flour presented approximate decrease of nine times the initial value,

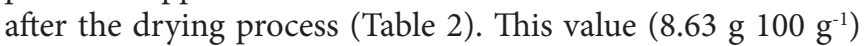
may indicate product stability regarding deterioration, since the maximum moisture recommended by ANVISA to store flours is $15 \%(\mathrm{~m} / \mathrm{m})$ (Brasil, 1978). Different from moisture, all other variables have shown increased component values when comparing the skin of the fruit with the flour. This information regards the ash, protein, lipid, fiber, and carbohydrate contents and, consequently, the energy value (Table 2).However, Ferreira et al. (2012) have found higher values in each variable assessed in the

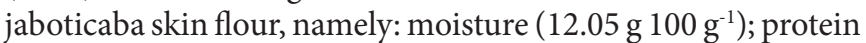

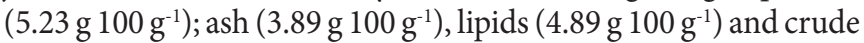

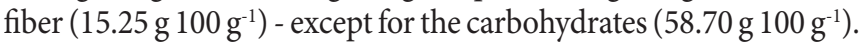

Table 2. Physical and chemical characterization of the skin and jaboticaba skin flour.

\begin{tabular}{|c|c|c|c|}
\hline \multirow{2}{*}{ Parameters } & \multicolumn{2}{|c|}{ Samples $^{1}$} & \multirow{2}{*}{$\mathrm{CV}(\%)^{2}$} \\
\hline & Skin & JSF & \\
\hline Moisture (g $100 \mathrm{~g}^{-1}$ ) & $78.69^{\mathrm{a}}$ & $8.63^{\mathrm{b}}$ & 0.30 \\
\hline $\operatorname{Ash}\left(\mathrm{g} 100 \mathrm{~g}^{-1}\right)$ & $0.51^{\mathrm{b}}$ & $1.13^{\mathrm{a}}$ & 0.22 \\
\hline Protein $\left(\mathrm{g} 100 \mathrm{~g}^{-1}\right)$ & $2.31^{\mathrm{b}}$ & $3.77^{\mathrm{a}}$ & 0.29 \\
\hline Lipids (g $100 \mathrm{~g}^{-1}$ ) & $0.85^{\mathrm{b}}$ & $1.54^{\mathrm{a}}$ & 0.49 \\
\hline Crude fiber $\left(\mathrm{g} 100 \mathrm{~g}^{-1}\right)$ & $2.30^{\mathrm{b}}$ & $5.81^{\mathrm{a}}$ & 0.22 \\
\hline Carbohydrats (g $\left.100 \mathrm{~g}^{-1}\right)$ & $15.34^{\mathrm{b}}$ & $79.05^{\mathrm{a}}$ & 0.18 \\
\hline Energy value $\left(\mathrm{kcal} 100 \mathrm{~g}^{-1}\right)$ & $78.00^{\mathrm{b}}$ & $345.00^{\mathrm{a}}$ & 0.13 \\
\hline
\end{tabular}

${ }^{1}$ All results are expressed as Fresh Weight $(\mathrm{FW})$. Mean rates $(\mathrm{n}=3)$ followed by their standard deviation. Means followed by the same small letter in the same line do not statistically differ at $5 \%$ probability by Duncan test; JSF = Jaboticaba skin flour; ${ }^{2} \mathrm{CV}=$ Coefficient of variation.

Consequently, it affected the energy value (299.68 kcal $\left.100 \mathrm{~g}^{-1}\right)$ of the product, which, in turn, was lower than that observed in the current study.

It is worth highlighting that, according to the Brazilian Legislation (Brasil, 1998), the food should present values between

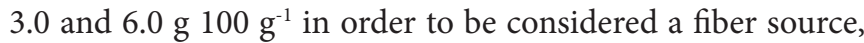
which classifies jaboticaba skin flour within these parameters

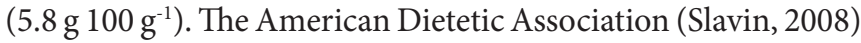
recommends daily fiber consumption from 20 to 30 grams for adults. Such recommendation allows inferring that the consumption of $100 \mathrm{~g}$ of jaboticaba skin flour represents $29.05 \%$ of the daily fiber consumption.

According to Ferreira et al. (2012), the high carbohydrate content in the jaboticaba skin flour developed in the current study allows using it to enrich breads, cookies and other food products. The energy value of the jaboticaba skin flour may be compared to that of flours commonly used by consumers, such as wheat $\left(360.0 \mathrm{kcal} 100 \mathrm{~g}^{-1}\right)$ and corn flours (351.0 kcal $\left.100 \mathrm{~g}^{-1}\right)$ (Universidade Estadual de Campinas, 2006). Thus, using jaboticaba skin flour as ingredient in certain products does not cause energy value increase.

The use of jaboticaba skin flour instead of wheat flour has changed some physicochemical features in the composition of the herein prepared cookies (Table 3 ). All the assessed features, as well as the four cookie formulations developed in the current study, have shown statistical differences $(p<0.05)$ between mean values. The highest energy value was found among the formulations developed in F3 (7.5\% JSF), and it was certainly associated with the greatest amount of jaboticaba skin flour $\left(345.0 \mathrm{kcal} 100 \mathrm{~g}^{-1}\right)$ added to the formulation.

The moisture of the cookies ranged from 0.92 (F2) to

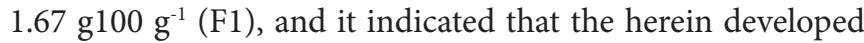
cookies showed storage stability, as well as good crispness, since the cookies' softness is directly linked to their moisture content. According to Campos Leite et al. (2005) and Moraes et al. (2010), the sucrose is dissolved when the cookie is baked and the moisture loss tends to crystallize the sucrose in the cooled cookie, thus making it crispier. 
Table 3. Physical and chemical characterization of cookies produced with the addition of jaboticaba skin flour.

\begin{tabular}{|c|c|c|c|c|c|}
\hline \multirow[b]{2}{*}{ Parameters } & \multicolumn{5}{|c|}{ Samples $^{1}$} \\
\hline & $\begin{array}{c}F 0 \\
(0.0 \%)\end{array}$ & $\begin{array}{c}F 1 \\
(2.5 \% \mathrm{JSF})\end{array}$ & $\begin{array}{c}F 2 \\
(5.0 \% \mathrm{JSF})\end{array}$ & $\begin{array}{c}F 3 \\
\text { (7.5\% JSF) }\end{array}$ & $\begin{array}{l}\mathrm{CV}^{2} \\
(\%)\end{array}$ \\
\hline Moisture (g $\left.100 \mathrm{~g}^{-1}\right)$ & $1.23^{\mathrm{b}}$ & $1.67^{\mathrm{a}}$ & $0.92^{\mathrm{d}}$ & $1.11^{\mathrm{c}}$ & 0.57 \\
\hline $\operatorname{Ash}\left(g_{\left.100 g^{-1}\right)}\right.$ & $1.52^{\mathrm{d}}$ & $1.56^{\mathrm{c}}$ & $1.67^{\mathrm{b}}$ & $1.87^{\mathrm{a}}$ & 0.35 \\
\hline Protein $\left(\mathrm{g} 100 \mathrm{~g}^{-1}\right)$ & $7.01^{\mathrm{d}}$ & $8.46^{\mathrm{a}}$ & $7.03^{c}$ & $7.43^{\mathrm{b}}$ & 0.24 \\
\hline 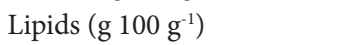 & $12.09^{\mathrm{d}}$ & $14.40^{c}$ & $14.67^{\mathrm{b}}$ & $17.20^{\mathrm{a}}$ & 0.05 \\
\hline Crude fiber $\left(\mathrm{g} 100 \mathrm{~g}^{-1}\right)$ & $3.80^{\mathrm{d}}$ & $4.78^{\mathrm{c}}$ & $5.33^{\mathrm{b}}$ & $6.04^{\mathrm{a}}$ & 0.43 \\
\hline Carbohydrats (g $\left.100 \mathrm{~g}^{-1}\right)$ & $74.36^{\mathrm{a}}$ & $69.14^{c}$ & $70.38^{\mathrm{b}}$ & $66.34^{\mathrm{d}}$ & 0.07 \\
\hline Energy value $\left(\mathrm{kcal} 100 \mathrm{~g}^{-1}\right)$ & $434.28^{\mathrm{d}}$ & $439.96^{\mathrm{b}}$ & $439.21^{\mathrm{c}}$ & $449.92^{\mathrm{a}}$ & 0.04 \\
\hline
\end{tabular}

${ }^{1}$ All results are expressed as Fresh Weight $(\mathrm{FW})$. Mean rates $(\mathrm{n}=3)$ followed by their standard deviation. Means followed by the same small letter in the same line do not statistically differ at $5 \%$ probability by Duncan test; JSF: Jaboticaba skin flour; ${ }^{2} \mathrm{CV}=$ Coefficient of variation.

The mineral content in the herein developed cookie formulations ranged from 1.52 (F1) to $1.87 \mathrm{~g}^{1} 100 \mathrm{~g}^{-1}$ (F3). The total mineral values have increased as the jaboticaba skin flour (JSF) addition rates increased, and it has indicated that the amount of these components increased due to the addition of such ingredient. These values were under the maximum limit $\left(3.0 \mathrm{~g} 100 \mathrm{~g}^{-1}\right)$ set by the Brazilian Legislation (Brasil, 1998), fact that enables its use.

The protein content of the cookies ranged from 7.01 (F0) to

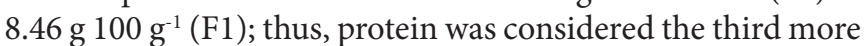
prevalent component. The results found in the current study allowed inferring that a significant portion of the total protein found in the cookies derived from the JSF, whose mean protein

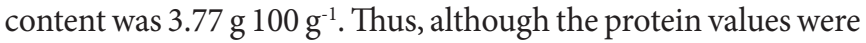
relatively low in comparison to those found in animal-origin products, according to Fasolin et al. (2007), it is worth taking into consideration that there are food production programs in Brazil that aim to reduce the animal protein in the diet through the replacement of it by vegetable-origin proteins, because these proteins demand lower costs. The protein values found in the current study corroborate those found by Fasolin et al. (2007) and Santos et al. (2014), which ranged from 6.77 to $7.80 \mathrm{~g}^{-1} 100 \mathrm{~g}$

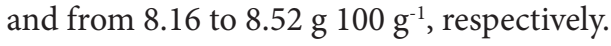

The lipid amount in the cookies has increased as the JSF addition increased and it was approximately 1.5 times higher in the formulation containing 7.5\% JSF (F3) when it was compared to the standard formulation (F0). The increase in the amount of lipids in the developed formulations is possibly due to the increment of added jaboticaba shell flour (2.50 5.00 7.50\%), since the amount of lipids added in formulation was constant, varying only the proportion of jaboticaba bark flour with $1.54 \%$ of lipids.

The lipid content is a basic component in the formulation of cookies and it is found at high levels (Jacob \& Leelavathi, 2007), fact that contributes to the softness of the cookies (Perry et al., 2003). A study conducted by Santos et al. (2014) used different lemon flour rates in the preparation of cookies and found lipid

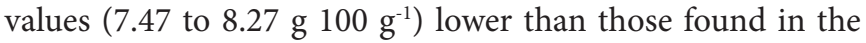
current study.

The fiber content, as well as the lipid content, have increased in the formulations as the JSF increased and it makes JSF favorable for human consumption. This increase in fiber content in the biscuit formulations is due to the increase of the added jaboticaba flour, considering that it has approximately 2.5 more fibers than the in natura fruit peel. It shows that the addition of fiber-source ingredients to food products has been encouraged (Mello \& Laaksonen, 2009), because these ingredients are directly associated with the prevention of diseases such as colon cancer, obesity, cardiovascular disorders and diabetes (Salgado et al., 2008). A study conducted by dos Santos et al. (2014) has found crude fiber content values ranging from 0.92 to $1.29{\mathrm{~g} 100 \mathrm{~g}^{-1}}^{-1}$ in cookies added with lemon skin flour. Such values were lower than those found in the current study.

The standard formulation (F0) has shown the highest carbohydrate content values although the JSF presented mean

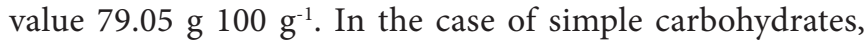
sugar has helped improving the texture, flavor, sweetness and color (Ormenese et al., 2001), as well as the energy value of the cookies. Santos et al. (2014) found values ranging from

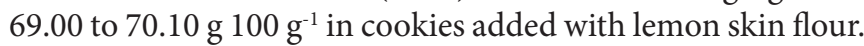

\subsection{The bioactive compounds and the antioxidant activity found in both the jaboticaba skin and the jaboticaba skin flour}

The analysis of bioactive compounds has shown that these compounds were mostly concentrated in the flour after the fruit dehydration process (Table 4). However, the potential antioxidant activity rates were reduced.

Studies have shown positive relation between the phenolic compound increase and the antioxidant activity potential (Madrau et al., 2010, 2009; Wojdyło et al., 2016; Chang et al., 2016). However, such relation was not straight in the current study. The reduced antioxidant activity in the flour may be related to the binding capacity of certain antioxidant compounds that remain in flours enriched with Trolox ${ }^{\circledR}$, as well as to potential losses that take place during the drying process, as described by Li et al. (2011).

Different phenolic compounds and some non-phenolic substances found in the fruit may have antioxidant activity (Tiveron et al., 2012). Thus, high phenolic compound levels may not mean greater antioxidant potential. The ascorbic acid (vitamin C) may be one of these compounds, since it has significant antioxidant activity and presents high electron donating capacity (Rufino et al., 2010; Wu et al., 2013). Such fact was also confirmed by Rufino et al. (2010), who have shown positive correlation between vitamin $\mathrm{C}$ and antioxidant activity. 
Table 4. Bioactive compounds and antioxidant activity of the skin and jaboticaba skin flour.

\begin{tabular}{lrrc}
\hline \multicolumn{1}{c}{ Bioactive compounds } & Skin & Flour & CV $(\%)^{7}$ \\
\hline Total Phenolic Compounds $^{1}$ & $1.19^{\mathrm{b}}$ & $2.45^{\mathrm{a}}$ & 0.55 \\
Total Flavonoids $^{2}$ & $53.43^{\mathrm{b}}$ & $110.97^{\mathrm{a}}$ & 1.64 \\
Total Anthocyanin $^{3}$ & $32.58^{\mathrm{b}}$ & $41.93^{\mathrm{a}}$ & 1.71 \\
Total Tanins $^{4}$ & $4.94^{\mathrm{b}}$ & $6.47^{\mathrm{a}}$ & 9.57 \\
\hline \multicolumn{1}{c}{ Antioxidant activity } & & & \\
\hline TEAC $^{5}$ & $638.66^{\mathrm{a}}$ & $468.54^{\mathrm{b}}$ & 0.18 \\
FRAP $^{6}$ & $242.73^{\mathrm{a}}$ & $169.17^{\mathrm{b}}$ & 1.83 \\
\hline
\end{tabular}

All results are expressed as Fresh Weight $(\mathrm{FW})$. Mean rates $(n=3)$ followed by their standard deviation. Means followed by the same small letter in the same line do not statistically differ at $5 \%$ probability by Duncan test; ${ }^{1} \mathrm{mg} \mathrm{GAE}$ g flour ${ }^{-1} ;{ }^{2} \mathrm{CE}=$ Catequin Equivalent; ${ }^{3} \mathrm{mg}$ of cyanidin-3-glucoside $100 \mathrm{~g}_{\text {flour }}{ }^{-1} ;{ }^{4} \mathrm{~g} 100 \mathrm{~g} \mathrm{~g}^{-1} ;{ }^{5} \mathrm{TEAC}=$ Trolox ${ }^{\circledR}$ Equivalent Antioxidant Capacity; ${ }^{6}$ FRAP $=$ Ferric Reducing Antioxidant Power; ${ }^{7} \mathrm{CV}=$ Coefficient of variation.

The use of high temperatures during the drying process has reduced vitamin C levels (Wojdyło et al., 2016), fact reported by studies that have used heat application and investigated fruit storage for long periods at low temperatures (Jacques et al., 2010; Chang et al., 2016). Tiveron et al. (2012) have reported that the ascorbic acid found in vegetables such as broccoli, cabbage, green onions, parsley, rocket and watercress may have contributed to their antioxidant activity. Such behavior was similar to that found in the current study.

The current study has used indirect methods to measure the antioxidant activity such methods comprised electron transfer. However, it may not necessarily correspond to oxidative degradation. It may explain the results obtained in the study, since they may depend on the chemical composition and on the principles of analysis. Thus, it is necessary using further analytical methods in order to get to a complete diagnosis, although it would make the present task onerous, expensive and unnecessary to the aim of the current research.

The concentration of total phenols (Table 4) was significant and increased due to dehydration. The herein found values were similar to those found by Lima et al. (2008), who have studied the same type of jaboticaba (Açú Paulista), as well as the variety 'jaboticaba Sabará (P. jaboticaba). In addition, the present results were superior to those found in other studies comprising fresh or dried fruits (Rufino et al., 2010; Wu et al., 2013; Silva et al., 2014; Rodrigues et al., 2015).

Flavonoids and tannins are subclasses of compounds within the phenolic compounds. The flavonoids and tannins in the current study remained at high levels and became concentrated due to dehydration. Abe et al. (2012) have found flavonoid levels lower than those found in the jaboticaba variety investigated in the current study (33.0 mg CE $\left.100 \mathrm{~g} \mathrm{~g}^{-1}\right)$. On the other hand, Dessimoni-Pinto et al. (2011) have reported that jaboticaba skin is rich in flavonoids (87.0\%)

The amount of anthocyanins - a flavonoid class sensitive to high temperatures (Chang et al., 2016) - found in the jaboticaba flour was $28 \%$ higher than that found in the fresh skin (Table 4). Although with the loss of anthocyanins content with the heat, there remains a significant proportion, making it a great ingredient with functional properties. Lima et al. (2011) described the relationship between the presence of anthocyanins and antioxidant capacity of the peel, seed and pulp of jaboticaba. However, anthocyanins correspond to a small portion of the phenolic compounds that exhibit these activities. In the present study we demonstrated the ratio of antioxidant to phenolic compounds, including anthocyanins.

Although the drying treatment has led to the concentration of bioactive compounds, it also resulted in the loss of some nutritionally-important compounds. However, keeping these bioactive compounds in the jaboticaba skin flour, even at low concentrations, is essential to the development of food products such as nutrients and potential bioactive compounds.

Tannins are compounds often considered undesirable in food products, because they add astringency to these products. However, these compounds contribute to antioxidant activity (Oszmianski et al., 2007; Gu et al., 2008). The jaboticaba skin has shown moderate levels of condensed tannins in comparison to fruits such as guava, cattley guava and Brazilian cherry. The data about jaboticaba skin flour (JSF) have shown its potential to be used as ingredient in food processing. These data corroborate other studies that highlight the potential of jaboticaba (Leite-Legatti et al., 2012; Lenquiste et al., 2015).

\subsection{The bioactive compounds and the antioxidant activity found in the cookies}

The JSF addition to cookies has led to increased bioactive compound levels, as well as to increased antioxidant activity potential (Table 5).

The content of total phenolic compounds in the cookies have shown statistical significant differences $(\mathrm{p}<0.05)$ between formulations (Table 5). A small portion of these compounds may be linked to the phenols found in oat, mainly flavonoids. The increased JSF addition has increased the amount of phenolic compounds in the cookies; these phenolic compounds are associated with those found in the jaboticaba skin. The levels of total phenolic compounds have shown linear increase (Figure 1A), and it indicated that the higher the amount of JSF used, the higher the content of compounds with bioactive action in the final product.

The total flavonoid, anthocyanin and tannin contents were statistically different $(\mathrm{p}<0.05)$ in the four cookie formulations. The flavonoid content found in the cookie with $0 \%$ JSF may be attributed to the oat, which has flavonoids in its composition (avenanthramides) (Koenig et al., 2011), as well as to the compounds derived from the Maillard reaction and to species that allow making readings at the same wavelength of the flavonoids. All four formulations have shown increased flavonoid content as the JSF addition increased, and it proved the permanence of part of the compounds after the cooking process. The increasing linear model adjustment to the total flavonoid content was significant and showed the behavior of this variable in the formulation of cookies (Figure 1B). It was possible seeing that the larger the JSF addition in the formulation of the cookies, the higher the flavonoid content in it. Consequently, it allowed increasing the biologically active properties. 
The anthocyanin content has also increased as the proportion of jaboticaba skin flour increased to the cookie. Thus, such compound was kept due to the addition of larger JSF amounts.
The tannins, as well as other phenolic compounds, are susceptible to heat and partially or totally destroyed by thermal processes (Sharma \& Gujral, 2014).

Table 5. Bioactive compounds and antioxidant activity of the cookie.

\begin{tabular}{|c|c|c|c|c|c|}
\hline Bioactive Compounds & $\begin{array}{c}F 0 \\
(0.0 \%) \\
\end{array}$ & $\begin{array}{c}F 1 \\
(2.5 \% \mathrm{JSF}) \\
\end{array}$ & $\begin{array}{c}F 2 \\
(5.0 \% \mathrm{JSF})\end{array}$ & $\begin{array}{c}F 3 \\
(7.5 \% \mathrm{JSF}) \\
\end{array}$ & $\begin{array}{l}\mathrm{CV}^{7} \\
(\%) \\
\end{array}$ \\
\hline Total Phenolic Compounds ${ }^{1}$ & $0.44^{\mathrm{d}}$ & $1.70^{c}$ & $2.44^{\mathrm{b}}$ & $2.79^{\mathrm{a}}$ & 4.85 \\
\hline Total Flavonoids ${ }^{2}$ & $3.20^{\mathrm{d}}$ & $15.54^{\mathrm{c}}$ & $16.42^{\mathrm{b}}$ & $18.87^{\mathrm{a}}$ & 1.97 \\
\hline Total Anthocyanin ${ }^{3}$ & $0.02^{c}$ & $1.63^{\mathrm{b}}$ & $2.52^{\mathrm{ab}}$ & $3.69^{\mathrm{a}}$ & 1.99 \\
\hline Total Tanins ${ }^{4}$ & $0.39^{\mathrm{d}}$ & $0.45^{\mathrm{c}}$ & $0.82^{\mathrm{b}}$ & $0.89^{\mathrm{a}}$ & 0.64 \\
\hline \multicolumn{6}{|l|}{ Antioxidant activity } \\
\hline TEAC $^{5}$ & $0.00^{\mathrm{d}}$ & $56.90^{c}$ & $108.34^{\mathrm{b}}$ & $147.93^{\mathrm{a}}$ & 1.96 \\
\hline FRAP $^{6}$ & $5.81^{\mathrm{d}}$ & $23.41^{\mathrm{c}}$ & $28.29^{\mathrm{b}}$ & $67.78^{\mathrm{a}}$ & 1.33 \\
\hline
\end{tabular}

All results are expressed as Fresh Weight $(\mathrm{FW})$. Mean rates $(\mathrm{n}=3)$ followed by their standard deviation. Means followed by the same small letter in the same line do not statistically differ at $5 \%$ probability by Duncan test; ${ }^{1} \mathrm{mg}$ GAE g flour ${ }^{-1} ;{ }^{2} \mathrm{CE}=$ Catequin Equivalent; ${ }^{3} \mathrm{mg}$ of cyanidin-3-glucoside $100 \mathrm{~g} \mathrm{flour}{ }^{-1} ;{ }^{4} \mathrm{~g} 100 \mathrm{~g}^{-1} ;{ }^{5} \mathrm{TEAC}=$ Trolox ${ }^{\oplus}$ Equivalent Antioxidant Capacity; ${ }^{6} \mathrm{FRAP}=$ Ferric Reducing Antioxidant Power; ${ }^{7} \mathrm{CV}=$ Coefficient of variation.
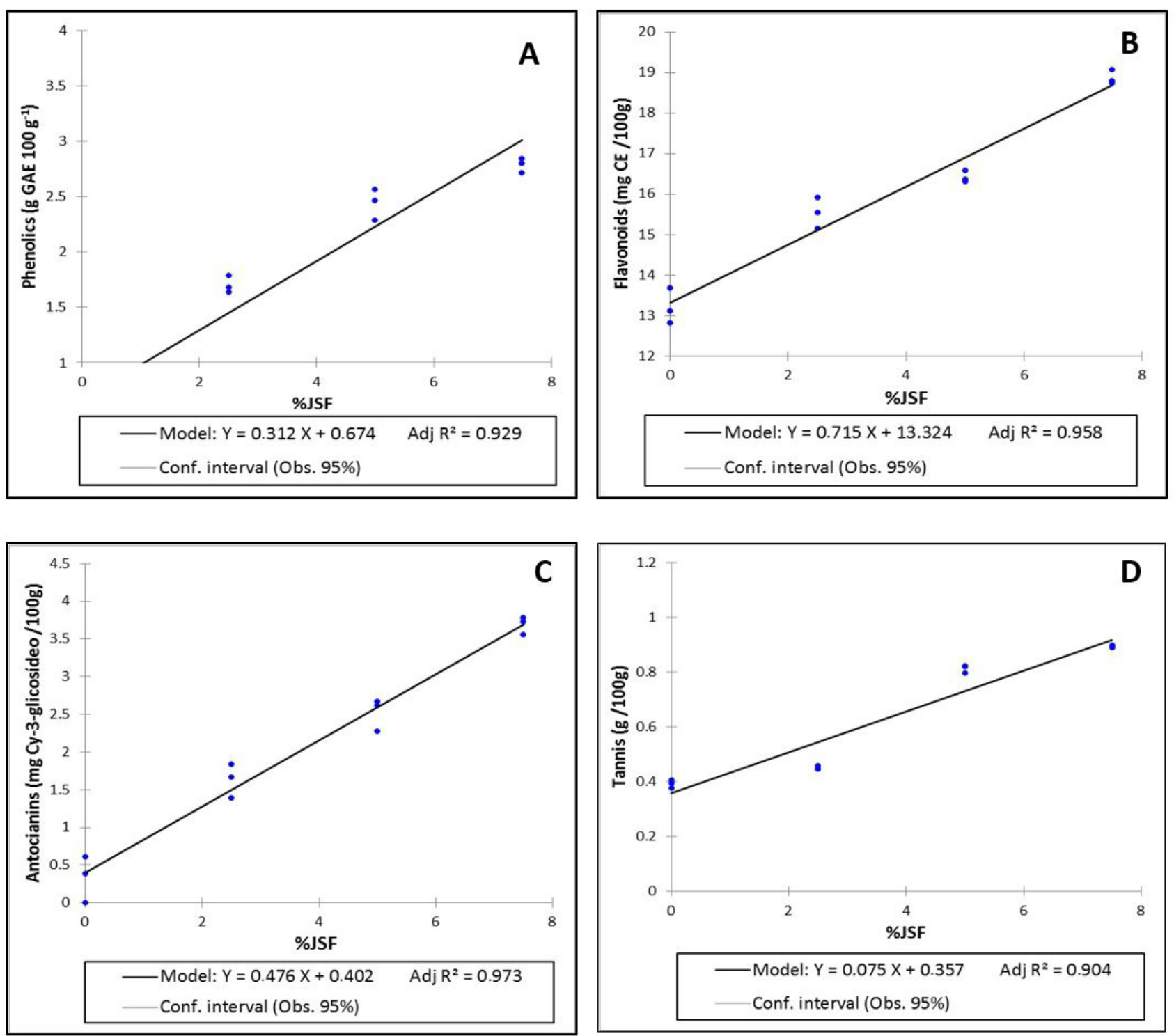

Figure 1. Total Phenolic Compounds (A), Total Flavonoid, (B), Total Anthocyanins (C) and Tannin Contents (D) of cookie according to the percentage of JSF. 
The antioxidant activity expressed as TEAC (0.00 to $\left.147.93 \mu \mathrm{MTEg}^{-1}\right)$ and FRAP (5.81 to $67.78 \mu \mathrm{M} \mathrm{FeSO}_{4} \mathrm{~g}^{-1}$ ) was statistically different $(\mathrm{p}<0.05)$ in cookies containing different JSF rates. The antioxidant activity of the cookie formulations has increased as larger JSF amounts were added to them. Thus, it confirmed the incorporation of bioactive compounds, as well as the conservation of part of these compounds after the heat treatment. Davidov-Pardo et al. (2012) have assessed cookies added with grape seed extract and found antioxidant activity levels close to those of cookies added with $2.5 \%$ JSF. On the other hand, Sharma \& Gujral (2014) have assessed cookies prepared with wheat flour and barley and found lower antioxidant activity in formulations containing 0 to $100 \%$ wheat flour.

The variable 'DPPH antioxidant activity', which was expressed as TEAC, has shown quadratic behavior (Figure 2B), whose maximum point was found at $18.05 \mathrm{~g} .100 \mathrm{~g}^{-1}$ of jaboticaba skin flour in the cookie composition, and it allowed reaching $225.38 \%$ antioxidant activity. This index is of interest because it can be used to measure the exact JSF amount required to achieve the best antioxidant rate. However, the fractions of JSF concentration must be limited, because they tend to compromise the technological properties of the cookies, as well as the tannic flavor of the flour. The antioxidant potential expressed as FRAP in the JSF-free cookie may be associated with ingredients - such as oat - added to the cookies, since these ingredients contained phenolic compounds, as well as compounds able to reduce Fe III to Fe II in products derived from the Maillard reaction (melanoidins) (Yilmaz \& Toledo, 2005). Despite the losses caused by the cooking process, it was possible formulating cookies able to keep the desired features and significant antioxidant potential in order to provide consumers with food containing functional properties that help preventing many diseases.

\subsection{Sensory analysis}

Table 6 shows the results found in the acceptance test. The cookie samples $(2.5 \%),(5.0 \%)$ and $(7.5 \%)$ have shown no significant differences in attributes such as flavor, texture, odor and overall impression when they were compared to the standard formulation $(0.0 \%)$, in the Kruskall-Wallis test (5.0\%). This is a desirable result, since the addition of jaboticaba skin flour, regardless of the amount, has led to consumer acceptance similar to that of JSF-free cookies. In the present study, preliminary tests indicated that the amount of FCJ to be applied to cookies interferes in the acceptance of the product, since they incorporate compounds characterized by bitterness and excessive astringency (tannins). This fact was also discribed by Ferreira et al. (2012). On the other hand, Zago et al. (2015) described a positive effect of the addition of FCJ in cookie for school food. However, the authors used vanilla essence, which interfered in the sensorial evaluation of the product.

Each cookie sample in Figure 2 is represented by a score. Each score corresponds to the mean value attributed by the sensory team. Similar samples occupy nearby regions in the chart and they are featured by the vectors (attributes) closer to them. It is possible seeing that the samples were different from

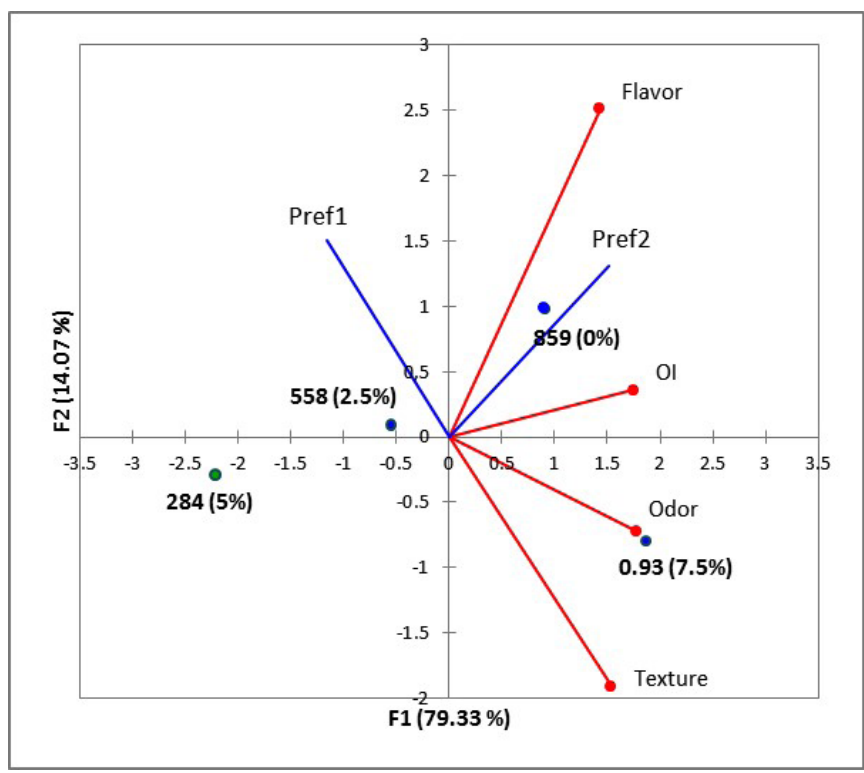

Figure 2. Main component analysis with sensory parameters of the cookie according to the percentage of adding jaboticaba skin flour; Pref $=$ Preference in purchase intention; F1 and F2 = Principal Component (vector).

Table 6. Acceptance for flavor, texture, odor and overall impression of the cookie added JSF.

\begin{tabular}{ccccc}
\hline & \multicolumn{4}{c}{ Variáveis analisadas $^{1}$} \\
\cline { 2 - 5 } Samples & Flavor & Texture & Odor & $\begin{array}{c}\text { Overall } \\
\text { impression }\end{array}$ \\
\hline F0 (0.0\%) & $7.30^{\mathrm{a}}$ & $7.20^{\mathrm{a}}$ & $7.19^{\mathrm{a}}$ & $7.28^{\mathrm{a}}$ \\
$\mathbf{F 1}(\mathbf{2 . 5 \%} \mathrm{JSF})$ & $7.22^{\mathrm{a}}$ & $7.09^{\mathrm{a}}$ & $7.23^{\mathrm{a}}$ & $7.31^{\mathrm{a}}$ \\
$\mathbf{F 2}(\mathbf{5 . 0 \%} \mathrm{JSF})$ & $7.08^{\mathrm{a}}$ & $7.04^{\mathrm{a}}$ & $7.12^{\mathrm{a}}$ & $7.05^{\mathrm{a}}$ \\
$\mathbf{F 3}(\mathbf{7 . 5 \%} \mathrm{JSF})$ & $7.22^{\mathrm{a}}$ & $7.30^{\mathrm{a}}$ & $7.33^{\mathrm{a}}$ & $7.09^{\mathrm{a}}$ \\
\hline${ }^{1}$ Means of scores of sensory with 100 consumers. The same small letter in the \\
same columns do not statistically differ at 5\% probability by Kruskall-Wallis test; \\
JSF = Jaboticaba skin flour.
\end{tabular}

each other, since they are marked in well-defined locations in each quadrant in Figure 2.

By analyzing the first principal component that reproduced $79.33 \%$ of the variability between samples, it was found that the standard formulation $(0.00 \%)$ had more positive scores and that it was better represented by the sensory attributes 'flavor' and 'overall impression', fact that was confirmed through the highest means presented by these attributes (Table 6).

The vectors Pref- 1 and Pref- 2 were generated according to the purchase intent and they highlighted the samples presenting the highest purchase intention by consumers. The cookie sample (7.50\%) may have had more negative than positive scores, because the highest means were attributed to odor and texture. Much of the variation between samples was explained by the Principal Component 1 . However, when such variation was assessed and associated with the Principal Component 2 , the two components explained $93.40 \%$ of the information about the mean values of the five sensory variables, i.e., the variability between samples could be well explained by using just these two axes (Figure 2). 


\section{Conclusion}

The jaboticaba skin, which is often discarded or seen as waste, shows significant amounts of bioactive compounds and antioxidant activity, as well as interesting chemical and mineral composition, according to nutritional and human health perspectives.

The JSF kept much of the bioactive compounds, presented high phenolic content and kept the antioxidant potential. The cookies developed through JSF addition have shown positive and significant bioactive compound increase. Thus, it kept the antioxidant activity found in the fruit. The sensory analysis has revealed that the favorite sample of the appraisers was the formulation containing $2.5 \%$ JSF. However, all formulations have shown good sensory acceptance, nutritional quality, as well as good quality of bioactive compounds.

\section{Acknowledgements}

The authors would like to thank, Araucária Foundation, CNPq and University of Technology Federal of Paraná (UTFPR) for funding and scholarship.

\section{References}

Abe, L. T., Lajolo, F. M., \& Genovese, M. I. (2012). Potential dietary sources of ellagic acid and other antioxidants among fruits consumed in Brazil: jaboticaba (Myrciaria jaboticaba (Vell.) Berg). Journal of the Science of Food and Agriculture, 92(8), 1679-1687. http://dx.doi. org/10.1002/jsfa.5531. PMid:22173652.

Addinsoft. (2015). XLSTAT 2015: data analysis and statistical solution for microsoft excel. Barcelona: Addinsoft Corporation.

Alcântara, S. R., Sousa, C. A. B., Almeida, F. A. C., \& Gomes, J. P. (2012). Caracterização físico-quimica das farinhas do pedúnculo do caju e da casca do maracujá. Revista Brasileira de Produtos Agroindustriais, 14, 473-478. http://dx.doi.org/10.15871/1517-8595/ rbpa.v14nEspecialp473-478.

Alkarkhi, A. F. M., Ramli, S. B., Yong, Y. S., \& Easa, A. M. (2011). Comparing physicochemical properties of banana pulp and peel flours prepared from green and ripe fruits. Food Chemistry, 129(2), 312-318. http://dx.doi.org/10.1016/j.foodchem.2011.04.060.

Ascheri, D. P. R., Andrade, C. T., Carvalho, A. W. P., \& Ascheri, J. L. R. (2006). Efeito da extrusão sobre a adsorção de água de farinhas mistas pré-gelatinizadas de arroz e bagaço de jaboticaba. Food Science and Technology, 26(20), 325-335. http://dx.doi.org/10.1590/ S0101-20612006000200015.

Bligh, E. G., \& Dyer, W. J. (1959). A rapid method for total lipid extraction and purification. Canadian Journal of Biochemistry and Physiology, 37(8), 911-917. http://dx.doi.org/10.1139/o59-099. PMid:13671378.

Borges, A. M., Pereira, J., \& Lucena, E. M. P. (2009). Caracterização da farinha de banana verde. Food Science and Technology, 29(2), 333-339. http://dx.doi.org/10.1590/S0101-20612009000200015.

Brand-Williams, W., Cuvelier, M. E., \& Berset, C. (1995). Use of free radical method evaluate antioxidant activity. LebensmittelWissenschaft + Technologie, 28(1), 25-30. http://dx.doi.org/10.1016/ S0023-6438(95)80008-5.

Brasil, Ministério da Saúde. Agência Nacional de Vigilância Sanitária - ANVISA. (1978, July 24). Regulamento técnico para produtos de cereais, amidos, farinhas e farelos (Resolução CNNPA no 12, de 24 de julho de 1978). Diário Oficial [da] República Federativa do Brasil.
Brasil, Ministério da Saúde. Agência Nacional de Vigilância Sanitária - ANVISA. (1998, January 16). Regulamento técnico referente à informação nutricional complementar (declarações relacionadas ao conteúdo de nutrientes) (Portaria $\mathrm{n}^{\circ} 31$, de 13 de janeiro de 1998). Diário Oficial [da] República Federativa do Brasil, seção 1.

Campos Leite, J. T., Murr, F. E. X., \& Park, K. J. (2005). Transições de fases em alimentos: influência no processamento e na armazenagem. Revista Brasileira de Produtos Agroindustriais, 7(1), 83-96.

Cavalcanti, R. N., Veggi, P. C., \& Meireles, M. A. A. (2011). Supercritical fluid extraction with a modifier of antioxidant compounds from jaboticaba (Myrciaria cauliflora) byoproducts: economic viability. Procedia Food Science, 1, 1672-1678. http://dx.doi.org/10.1016/j. profoo.2011.09.247.

Chang, S. K., Alasalvar, C., \& Shahidi, F. (2016). Review of dried fruits: phytochemicals, antioxidant efficacies, and health benefits. Journal of Functional Foods, 21, 113-132. http://dx.doi.org/10.1016/j. jff.2015.11.034.

Cruz, C. D. (2006). Programa genes: estatística experi $\neg$ mental e matrizes. Viçosa: Universidade Federal de Viçosa.

Dan, M. C. T., Cardenette, G. H. L., Sardá, F. A. H., Giuntini, E. B., Bello-Pérez, L. A., Carpinelli, Â. R., Lajolo, F. M., \& Menezes, E. W. (2015). Colonic fermentation of unavailable carbohydrates from unripe banana and its influence over glycemic control. Plant Foods for Human Nutrition, 70(3), 297-303. PMid:26092708.

Davidov-Pardo, G., Moreno, M., Arozarena, I., Marín-Arroyo, M. R., Bleibaum, R. N., \& Bruhn, C. M. (2012). Sensory and consumer perception of the addition of grape seed extracts in cookies. Journal of Food Science, 77(12), 430-438. http://dx.doi.org/10.1111/j.17503841.2012.02991.x. PMid:23170916.

Dessimoni-Pinto, N. A. V., Moreira, W. A., Cardoso, L. M., \& Pantoja, L. A. (2011). Jaboticaba peel for jelly preparation: an alternative technology. Food Science and Technology, 31(4), 864-869. http:// dx.doi.org/10.1590/S0101-20612011000400006.

Fasolin, L. H., Almeida, G. C. D., Castanho, P. S., \& Netto-Oliveira, E. R. (2007). Cookies produced with banana meal: chemical, physical and sensorial evaluation. Food Science and Technology, 27(3), 524-529. http://dx.doi.org/10.1590/S0101-20612007000300016.

Fernandes, A. F., Pereira, J., Germani, R., \& Oiano-Neto, J. (2008). Efeito da substituição parcial da farinha de trigo por farinha de casca de batata (Solanum tuberosum Lineu). Food Science and Technology, 28, 56-65. http://dx.doi.org/10.1590/S0101-20612008000500010.

Ferreira, A. E., Ferreira, B. S., Lages, M. M. B., Rodrigues, V. A. F., Thé, P. M. P., \& Pinto, N. A. V. D. (2012). Caracterização e uso da casca de jaboticaba em cookies. Alimentos e Nutrição, 23(4), 603-607.

Gu, H., Li, C., Xu, Y., Hu, W., Chen, M., \& Wan, Q. (2008). Structural features and antioxidant activity of tannin from persimmon pulp. Food Research International, 41(2), 208-217. http://dx.doi.org/10.1016/j. foodres.2007.11.011.

Instituto Adolfo Lutz - IAL. (2008). Normas analíticas do Instituto Adolfo Lutz: métodos físicos e químicos para análise de alimentos (4. ed.). São Paulo: IAL.

Jacob, J., \& Leelavathi, K. (2007). Effect of fat-type on cookie dough and cookie quality. Journal of Food Engineering, 79(1), 299-305. http:// dx.doi.org/10.1016/j.jfoodeng.2006.01.058.

Jacques, A. C., Pertuzatti, P. B., Barcia, M. T., Zambiazi, R. C., \& Chim, J. F. (2010). Estabilidade de compostos bioativos em polpa congelada de amora-preta (Rubus fruticosus) cv. Tupy. Quimica Nova, 33(8), 1720-1725. http://dx.doi.org/10.1590/S0100-40422010000800019.

Koenig, R. T., Dickman, J. R., Wise, M. L., \& Ji, L. L. (2011). Avenanthramides are bioavailable and accumulate in hepatic, cardiac and skeletal 
muscle tissue following oral gavage in rats. Journal of Agricultural and Food Chemistry, 59(12), 6438-6443. http://dx.doi.org/10.1021/ jf2002427. PMid:21417395.

Lee, J., Durst, R. W., \& Wrolstad, R. E. (2005). Determination of total monomeric anthocyanin pigment content of fruit juices, beverages, natural colorants, and wines by the $\mathrm{pH}$. Journal of AOAC International, 88(5), 1-10. PMid:16385975.

Leite-Legatti, A. V., Batista, Â. G., Dragano, N. R. V., Marques, A. C., Malta, L. G., Riccio, M. F., Eberlinb, M. N., Machadoc, A. R. T., Carvalho-Silvac, L. B., Ruizd, A. L. T. G., Carvalhod, A. E., Pastore, G. M., \& Maróstica, M. R., Jr. (2012). Jaboticaba peel: antioxidant compounds, antiproliferative and antimutagenic activities. Food Research International, 49(1), 596-603. http://dx.doi.org/10.1016/j. foodres.2012.07.044.

Lenquiste, S. A., Marineli, R. S., Moraes, E. A., Dionísio, A. P., Brito, E. S., \& Maróstica, M. R., Jr. (2015). Jaboticaba peel and jaboticaba peel aqueous extract shows in vitro and in vivo antioxidant properties in obesity model. Food Research International, 77(2), 162-170. http:// dx.doi.org/10.1016/j.foodres.2015.07.023.

Li, J., Walker, C. E., \& Faubion, J. M. (2011). Acidulant and oven type affect total anthocyanin content of blue corn cookies. Journal of the Science of Food and Agriculture, 91(1), 38-43. http://dx.doi. org/10.1002/jsfa.4173. PMid:20848670.

Lima, A. J. B., Corrêa, A. D., Saczk, A. A., Martins, M. P., \& Castilho, R. O. (2011). Anthocyanins, pigment stability and antioxidant activity in jaboticaba Myrciaria cauliflora (Mart.) O. Berg]. Revista Brasileira de Fruticultura, 33(3), 877-887. http://dx.doi.org/10.1590/ S0100-29452011000300023.

Lima, A. J., Corrêa, A. D., Alves, A. P. C., Abreu, C. M. P., \& Dantas, B. A. M. (2008). Caracterização química do fruto jaboticaba (Myrciaria cauliflora Berg) e de suas frações. Archivos Latinoamericanos de Nutricion, 58(4), 416-421. PMid:19368305.

Lima, D. M., Colugnati, F. A. B., Padovani, R. M., Amaya, D. B. R., Salay, E., \& Galeazzi, M. A. M. (2006). Tabela brasileira de composição de alimentos (TACO). Campinas: Núcleo de Estudos e Pesquisas em Alimentação.

Lopes, L. D., Cavalli, K. F., Böger, B. R., Silveira-Junior, J., Osorio, D., Lucchetta, L., \& Tonial, I. B. (2014). Fatty acid profile, quality lipid index and bioactive compounds of flour from grape residues. Ciencia e Investigación Agraria, 41(2), 225-234. http://dx.doi.org/10.4067/ S0718-16202014000200008.

Madrau, M. A., Piscopo, A., Sanguinetti, A. M., Del Caro, A., Poiana, M., Romeo, F. V., \& Piga, A. (2009). Effect of drying temperature on polyphenolic content and antioxidant activity of apricots. European Food Research and Technology, 228(3), 441-448. http://dx.doi. org/10.1007/s00217-008-0951-6.

Madrau, M. A., Sanguinetti, A., Del Caro, A., Fadda, C., \& Piga, A. (2010). Contribution of melanoidins to the antioxidant activity of prunes. Journal of Food Quality, 33, 155-170. http://dx.doi. org/10.1111/j.1745-4557.2010.00328.x.

Mello, V. D., \& Laaksonen, D. E. (2009). Fibras na dieta: tendências atuais e benefícios à saúde na síndrome metabólica e no diabetes melito tipo 2. Arq. Bras. de End. e Met., 53(5), 509-518.

Moraes, K. S. D., Zavareza, E. D. R., Miranda, M. Z. D., \& Salas-Mellado, M. M. (2010). Technological evaluation of cookies with lipid and sugar content variations. Food Sc. and Tech., 30, 233-242. http:// dx.doi.org/10.1590/S0101-20612010000500036.

Oliveira, A. L., Brunini, M. A., Salandini, C. A. R., \& Bazzo, F. R. (2003). Caracterização tecnológica de jaboticabas 'Sabará provenientes de diferentes regiões de cultivo. Revista Brasileira de Fruticultura, 25(3), 397-400. http://dx.doi.org/10.1590/S0100-29452003000300009.
Ormenese, R. C. S. C., Marchese, D. A., Lage, M. E., Mamede, M. E. O., Abreu, G. M. N., Coelho, H. D., Moura, J. M. L. N., Nishi, L. E., Carrilho, N. A., González, N. B., \& Da Silva, M. A. A. P. (2001). Perfil sensorial e teste de consumidor de biscoito recheado sabor chocolate. Boletim do Centro de Pesquisa e Processamento de Alimentos, 19(2), 277-300. http://dx.doi.org/10.5380/cep.v19i2.1239.

Osborne, D. R., \& Voogt, P. (1978). The analysis of nutrient in foods. London: Academic Press.

Oszmianski, J., Wojdyło, A., Lamer-Zarawska, E., \& Swiader, K. (2007). Antioxidant tannins from Rosaceae plant roots. Food Chemistry, 100(2), 579-583. http://dx.doi.org/10.1016/j.foodchem.2005.09.086.

Perry, J. M., Swanson, R. B., Lyon, B. G., \& Savage, E. M. (2003). Instrumental and sensory assessment of oatmeal and chocolate chip cookies: modified with sugar and fat replacers. Cereal Chemistry, 80(1), 45-51. http://dx.doi.org/10.1094/CCHEM.2003.80.1.45.

Queiroz, C. R. A. A., Morais, S. A. L., \& Nascimento, E. A. (2002). Caracterização dos taninos da aroeira-preta (Myracrodruon urundeuva). Revista Árvore, 26(4), 485-492. http://dx.doi.org/10.1590/ S0100-67622002000400011.

Rodrigues, S., Fernandes, F. A., de Brito, E. S., Sousa, A. D., \& Narain, N. (2015). Ultrasound extraction of phenolics and anthocyanins from jaboticaba peel. Industrial Crops and Products, 69, 400-407. http://dx.doi.org/10.1016/j.indcrop.2015.02.059.

Rufino, M. S. M., Alves, R. E., Brito, E. S., Morais, S. M., Sampaio, C. G., Pérez-Jiménez, J., \& Saura-Calixto, F. D. (2006). Metodologia científica: determinação da atividade antioxidante total em frutas pelo método de redução do ferro (FRAP) (Comunicado Técnico Online, Vol. 125). Fortaleza: Embrapa Agroindústria Tropical.

Rufino, M. S. M., Alves, R. E., Brito, E. S., Morais, S. M., Sampaio, C. G., Pérez-Jiménez, J., \& Saura-Calixto, F. D. (2007). Metodologia científica: determinação da atividade antioxidante total em frutas pela captura do radical livre DPPH (Comunicado Técnico Online, Vol. 127). Fortaleza: Embrapa Agroindústria Tropical.

Rufino, M. S. M., Alves, R. E., Brito, E. S., Pérez-Jiménez, J., SauraCalixto, F., \& Mancini-Filho, J. (2010). Bioactive compounds and antioxidant capacities of 18 non-traditional tropical fruits from Brazil. Food Chemistry, 121(4), 996-1002. http://dx.doi.org/10.1016/j. foodchem.2010.01.037.

Salgado, J. M., Bin, C., Mansi, D. N., \& Souza, A. (2008). Efeito do abacate (Persea americana Mill) variedade hass na lipidemia de ratos hipercolesterolêmicos. Food Science and Technology, 28(4), 922-928. http://dx.doi.org/10.1590/S0101-20612008000400025.

Santos, D. S. D., Storck, C. R., \& Fogaça, A. O. (2014). Biscoito com adição de farinha de casca de limão. Discip. Sc., 15(1), 123-135.

Santos, D. T., \& Meireles, M. A. A. (2009). Jaboticaba as a source of functional pigments. Plant Review, 3(5), 137-142.

Santos, D. T., Veggi, P. C., \& Meireles, M. A. A. (2010). Extraction of antioxidant compounds from Jaboticaba (Myrciaria cauliflora) skins: yield, composition and economical evaluation. Journal of Food Engineering, 101(1), 23-31. http://dx.doi.org/10.1016/j. jfoodeng.2010.06.005.

Sharma, P., \& Gujral, H. S. (2014). Cookie making behavior of wheatbarley flour blends and effects on antioxidant properties original. Lebensmittel-Wissenschaft + Technologie, 55(1), 301-307. http:// dx.doi.org/10.1016/j.lwt.2013.08.019.

Silva, M. C., Souza, V. B., Thomazini, M., Da Silva, E. R., Smaniotto, T., De Carvalho, R. A., \& Favaro-Trindade, C. S. (2014). Use of the jaboticaba (Myrciaria cauliflora) depulping residue to produce a natural pigment powder with functional properties. Lebensmittel- 
Wissenschaft + Technologie, 55(1), 203-209. http://dx.doi.org/10.1016/j. lwt.2013.08.026.

Singleton, V. L., Orthofer, R., \& Lamuela-Raventos, R. M. (1999). Analysis of total phenols and others oxidation substrates and antioxidants by mean Folin-Ciocalteau reagent. Methods in Enzymology, 299, 152-178. http://dx.doi.org/10.1016/S0076-6879(99)99017-1.

Slavin, J. L. (2008). Position of the American Dietetic Association: health implications of dietary fiber. Journal of the American Dietetic Association, 108(10), 1716-1731. http://dx.doi.org/10.1016/j. jada.2008.08.007. PMid:18953766.

Souza, M. W. S., Ferreira, T. B. O., \& Vieira, I. F. R. (2008). Composição centesimal e propriedades funcionais tecnológicas da farinha da casca do maracujá. Alimentos e Nutrição, 19(1), 33-36.

Stone, H., \& Sidel, J. L. (2004). Sensory evaluation practices (3. ed.). New York: Academic Press.

Tiveron, A. P., Melo, P. S., Bergamaschi, K. B., Vieira, T. M. F. S., RegitanoD'arce, M. A. B., \& Alencar, S. M. (2012). Antioxidant activity of brazilian vegetables and its relation with phenolic composition. International Journal of Molecular Sciences, 13(7), 8943-8957. http:// dx.doi.org/10.3390/ijms13078943. PMid:22942744.

Trueba, G. P., \& Sanchez, G. M. (2001). Los flavonoides como antioxidantes naturales. Latin American Journal of Pharmacy, 20, 297-306.
Universidade Estadual de Campinas - UNICAMP. (2006). Tabela brasileira de composição de alimentos (TACO) versão 2 (2. ed., pp. 30). Campinas: Núcleo de Estudos e Pesquisas em Alimentação.

Wojdyło, A., Figiel, A., Legua, P., Lech, K., Carbonell-Barrachina, Á. A., \& Hernández, F. (2016). Chemical composition, antioxidant capacity, and sensory quality of dried jujube fruits as affected by cultivar and drying method. Food Chemistry, 207, 170-179. http:// dx.doi.org/10.1016/j.foodchem.2016.03.099. PMid:27080894.

Wu, S. B., Long, C., \& Kennelly, E. J. (2013). Phytochemistry and health benefits of jaboticaba, an emerging fruit crop from Brazil. Food Research International, 54(1), 148-159. http://dx.doi.org/10.1016/j. foodres.2013.06.021.

Yilmaz, Y., \& Toledo, R. T. (2005). Antioxidant activity of water soluble Maillard reaction products. Food Chemistry, 93(2), 273-278. http:// dx.doi.org/10.1016/j.foodchem.2004.09.043.

Zago, M. F. C., Caliari, M., Soares, M. S., Jr., Campos, M. R. H., \& Batista, J. E. R. (2015). Jaboticaba peel in the production of cookies for school food: technological and sensory aspects. Ciência e Agrotecnologia, 39(6), 624-633. http://dx.doi.org/10.1590/S1413-70542015000600009.

Zhishen, J., Mengcheng, T., \& Jianming, W. (1999). The determination of flavonoid contents in mulberry and their scavenging effects on superoxide radical. Food Chemistry, 64(4), 555-559. http://dx.doi. org/10.1016/S0308-8146(98)00102-2. 